\title{
Potestas sacra według Klausa Mörsdorfa - założenia teologiczne, struktura, sposób przekazywania i charakter
}

\section{Wprowadzenie: potestas sacra w dokumentach Soboru Watykańskiego II}

W Roku Wiary, w 50 lat od otwarcia Soboru Watykańskiego II, warto pochylić się raz jeszcze nad nauczaniem soborowym ${ }^{1}$. Vaticanum II miało wielki

\footnotetext{
I Zachętę do tego dał sam Benedykt XVI, „ostatni papież Soboru”: „Uznałem, że zainaugurowanie Roku Wiary w połączeniu z 50. rocznicą otwarcia Soboru Watykańskiego II może być dobrą okazją do tego, aby zrozumieć, że teksty należące do spuścizny pozostawionej przez ojców soborowych, zgodnie ze słowami bł. Jana Pawła II, «nie traca wartości ani blasku. Konieczne jest, aby były należycie odczytywane, poznawane i przyswajane jako miarodajne i normatywne teksty Magisterium, należące do Tradycji Kościoła. Dzisiaj, po zakończeniu Jubileuszu, szczególnie mocno odczuwam powinność ukazywania Soboru jako wielkiej łaski, która stała się dobrodziejstwem dla Kościoła w XX wieku: został on dany jako niezawodna busola, wskazująca nam drogę w stuleciu, które się rozpoczyna» [Jan Paweł II, list apost. Novo millennio ineunte, 6 stycznia 2001, 57: AAS 93 (2001), 308]. Ja również pragnę z naciskiem potwierdzić to, co powiedziałem na temat Soboru kilka miesięcy po moim wyborze na Następcę Piotra: "Jeśli go odczytujemy i przyjmujemy w świetle prawidłowej hermeneutyki, może on być i coraz bardziej stawać się wielką mocą służącą zawsze potrzebnej odnowie Kościoła» [Przemówienie do Kurii Rzymskiej (22 grudnia 2005), AAS, R. 98 (2006), 52; "L'Osservatore Romano», wyd. polskie, n. 2/2006,
} 
wpływ na kodyfikację obowiązującego prawa kanonicznego ${ }^{2}$, ale nie zawsze jak się wydaje - kodyfikatorzy epoki soborowej potrafili do końca odczytać teksty soborowe.

Zdaje się też, że właśnie koncepcja potestas sacra („władzy świętej”, zwanej też dalej zamiennie „władzą kościelną”’), zawarta w tekstach magisterium soborowego i nieznana aż do czasów Vaticanum II w terminologii kanonistycznej ${ }^{4}$, nie została w pełni zrozumiana przez twórców kodeksu łacińskiego z 1983 roku, a następnie kodeksu wschodniego z 1990 roku. Zresztą, zagadnienie władzy kościelnej jest jednym z najbardziej dyskutowanych i najtrudniejszych zagadnień w kanonistyce, zwłaszcza w epoce soborowej ${ }^{5}$.

W konstytucji Lumen gentium po raz pierwszy wspomina się o potestas sacra w kontekście kapłaństwa powszechnego wiernych i kapłaństwa hierarchicznego ${ }^{6}$. Tylko kapłani urzędowi jednak (sacerdotes ministeriales) cieszą się

s. 20]" (Benedictus XVI, Litterae apostolicae motu proprio datae Porta fidei quibus Annus fidei inchoatur, 11 X 2011, nr 5, AAS, R. 103, 2011, s. 723-734; przekład polski wraz z oryginalną cytacją przypisów w nawiasach według: http://www.vatican.va/holy_father/benedict_xvi/motu_proprio/documents/hf_ben-xvi_motu-proprio_20111011_portafidei_pl.html, 05.03.2013; kursywa - w oryginale).

2 Zob. choćby Sobór Watykański II. Inspiracje i wptyw na Kodeks Prawa Kanonicznego z 1983 roku, red. K. Burczak, Lublin 2006.

3 Podobnie w doktrynie niemieckiej prawa kanonicznego, gdzie termin Kirchengewalt jest stosowany zamiennie z pojęciem potestas sacra (heilige Gewalt), geistliche Vollmacht, apostolische Vollmacht. Zakres pojęcia władzy kościelnej (potestas sacra) obejmuje zatem władzę święceń (potestas ordinis, Weihegewalt, Weihevollmacht) oraz władzę rządzenia czy jurysdykcji (potestas regiminis, potetas iurisdictionis, Jurisdiktions-, Hirtengewat, Leitungs-. Jurisdiktionsvollmacht). Zob. W. Aymans, K. Mörsdorf, Kanonisches Recht. Lehrbuch aufgrund des Codex Iuris Canonici, t. 1, Paderborn-München-Wien-Zürich 1991, s. 385386; P. Krämer, Die geistliche Vollmacht, [w:] Handbuch des katholischen Kirchenrechts, red. J. Listl, H. Schmitz, Regensburg 1999, s. 149.

4 Por. A. Cattaneo, Questioni fondamentali della canonistica nel pensiero di Klaus Mörsdorf, Pamplona 1986, s. 131.

5 Przedstawienie tej dyskusji (w postaci systematyki, z konieczności uogólniającej poglądy) w innym tekście Autora, por. P. Skonieczny, Teorie władzy kościelnej a stanowisko ks. prof. Józefa Krzywdy CM. Próba syntezy, [w:] Servabo legem Tuam in toto corde meo. Księga pamiątkowa dedykowana Księdzu Profesorowi Józefowi Krzywdzie CM, dyrektorowi Instytutu Prawa Kanonicznego UPJPII z okazji 70. rocznicy urodzin, red. A. Sosnowski CR, A. Zakręta CM, Kraków 2013, s. 459-466.

6 Dokładna analiza terminologiczna potestas sacra w tekstach soborowych, zob. P. Krämer, Dienst und Vollmacht in der Kirche. Eine rechtstheologische Untersuchung zur Sacra 
potestas sacra, dzięki której właśnie budują (efformare) lud kapłański i nim rządzą (regere) ${ }^{7}$. Myśl, że potestas sacra należy tylko do duchownych została jeszcze powtórzonå ${ }^{8}$. Apostołowie są przecież uczestnikami we władzy Jezusa Chrystusa (suae participes potestatis), który sam ich posłał?. Biskupi zaś, jako vicarii et legati Christi, rządzą w powierzonych sobie Kościołach partykularnych na mocy tej właśnie potestas sacra, wykonywanej w imieniu Chrystusa

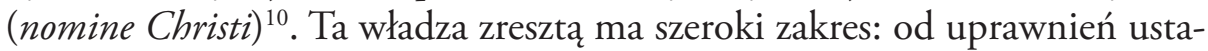
wodawczych przez sądownicze po kult i przepowiadanie ${ }^{11}$. Z kolei według dekretu Presbyterorum ordinis $\mathrm{w}$ tej potestas sacra uczestniczą także prezbiterzy jako „współpracownicy stanu biskupiego" (Ordinis episcopalis cooperatores $)^{12}$.

Odnośnie do przekazywania potestas sacra Sobór Watykański II wypowiedział się najpełniej we Wstępnej Nocie Wyjaśniającej dodanej do Lumen gentium. Poprzez konsekrację biskupią uczestniczy się „ontologicznie” w sacra munera (,święte zadania”), ale nie w potestas sacra, jak zauważa sam Sobór ${ }^{13}$. Munera sacra bowiem powinny zostać zaktualizowane czy zdeterminowane poprzez missio canonica właściwego autorytetu hierarchicznego ${ }^{14}$ : $\mathrm{w}$ ten sposób stają się potetas sacra. Nie wystarcza zatem sama communio poprzez otrzymaną sakrę biskupią; potrzeba „communio hierarchica” z Głową i z Ko-

Potestas-Lehre des II. Vatikanischen Konzils, Trier 1973, s. 18-22.

7 Por. LG 10, 2: „Sacerdos quidem ministerialis, potestate sacra qua gaudet, populum sacerdotalem efformat ac regit [...]" (kursywa - P. S.).

8 Zob. LG 18, 1: „Ministri enim, qui sacra potestate pollent, fratribus suis inserviunt [...]" (kursywa - P. S.).

9 Por. LG 19, 1.

1o Zob. LG 27, 1.

II Por. tamże: „Vi huius potestatis Episcopi sacrum ius et coram Domino officium habent in suos subditos leges ferendi, iudicium faciendi, atque omnia, quae ad cultus apostolatusque ordinem pertinent, moderandi”.

12 Zob. PO 2, 1, wcześniej odnosząc potestas sacra tylko do władzy święceń: „Idem vero Dominus, inter fideles, ut in unum coalescerent corpus, in quo «omnia membra non eundem actum habent» (Rom. 12, 4), quosdam instituit ministros, qui, in societate fidelium, sacra Ordinis potestate pollerent Sacrificium offerendi et peccata remittendi, atque sacerdotali officio publice pro hominibus nomine Christi fungerentur" (kursywa - P. S.).

${ }_{13}$ Por. NEP 2, 2: „In consecratione datur ontologica participatio sacrorum munerum, ut indubie constat ex Traditione, etiam liturgica. Consulto adhibetur vocabulum munerum, non vero potestatum, quia haec ultima vox de potestate ad actum expedita intelligi posset" (kursywa - w oryginale).

I4 Zob. tamże; LG 24, 2. 
legium Biskupów na mocy misji kanonicznej ${ }^{15}$. Sobór jasno stwierdza, że: „Ta wspólnota hierarchiczna wszystkich Biskupów z Papieżem jest na pewno uświęcona w Tradycji”"

Jak zatem widać, Sobór Watykański II jest bardzo powściągliwy w opisywaniu potestas sacra. Nie określa jej struktury ani natury; enigmatycznie wypowiada się co do jej przekazywania. Z jednej strony więc Vaticanum II pozostawia kanonistom (i nie tylko kanonistom) szerokie pole do interpretacji. Z drugiej zaś strony jednak w pewien sposób - jakkolwiek niepełny i niedomknięty - wskazuje na kierunki tej interpretacji.

Po pierwsze, termin potestas sacra $\mathrm{w}$ dokumentach soborowych określa całą i jedną władzę kościelną, pochodzącą od Jezusa Chrystusa. Konsekwentnie zatem pojęcie to należałoby rozciągnąć tak na władzę święceń, jak i na władzę rządzenia.

Po drugie, ta władza wyraźnie została ograniczona do duchownych, czyli do tych, którzy przyjęli święcenia.

Po trzecie wreszcie, munera sacra nie oznaczają jeszcze potestas sacra, gdyż sposób przekazywania tej ostatniej jest bardziej złożony i odbywa się za pomocą misji kanonicznej, zgodnie zresztą z „hermeneutyką reformy”, który to klucz do odczytywania Soboru Watykańskiego II zaproponował Benedykt XVI ${ }^{17}$.

Wydaje się, że najlepiej opisuje soborową koncepcję potestas sacra ks. prof. Klaus Mörsdorf (1909-1989), twórca szkoły monachijskiej (szkoły niemieckiej) prawa kanonicznego ${ }^{18}$. Jego interpretacja władzy kościelnej bowiem najwierniej - jak się zdaje - odpowiada nauce Vaticanum II, przestrzegając tych wszystkich ograniczeń interpretacyjnych, które narzucili ojcowie soborowi $^{19}$. Stąd warto bliżej przyjrzeć się koncepcji Klausa Mörsdorfa, tym

is Por. LG 22, 2; NEP 2.

i6 NEP 4, in fine. Przekład polski wg: Sobór Watykański II, Konstytucje, dekrety, deklaracje. Tekst łacińsko-polski, Paryż 1967, s. 175.

${ }_{17}$ Por. Benedictus XVI, Allocutio Expergiscere homo ad Romanam Curiam ob omina natalicia, 22 XII 2005, „Acta Apostolicae Sedis”, R. 98, 2006, s. 46.

I8 Odnośnie do tej szkoły zob. R. Sobański, Szkoły kanonistyczne, Warszawa 2009, s. $86-94$.

19 Jeszcze w epoce przedsoborowej K. Mörsdorf podkreślał niektóre wymiary doktryny o potestas sacra, zawarte później w Lumen gentium, a zwłaszcza wymiar pierwszy, o którym była mowa wyżej; zob. K. Mörsdorf, De sacra potestate, „Apollinaris”, R. 40, 1967, nr 1-4, s. 45; A. Cattaneo, Questioni..., dz. cyt., s. 131-132, 152. 
bardziej że miała ona duży wpływ na kanonistykę nie tylko niemiecką, ale i światową, w tym polską ${ }^{20}$.

Ze względu na ogromny obszar zagadnień związanych z władzą kościelną poniższe rozważania zostaną ograniczone do założeń teologicznych, struktury, natury i sposobu przekazywania potestas sacra. Pominięte zostaną natomiast takie zagadnienia, jak: zakres wewnętrzny i zewnętrzny władzy kościelnej, pozycja świeckich, relacja Biskup Rzymu - Kolegium Biskupów, władza biskupa diecezjalnego, urząd kościelny itd. ${ }^{21}$.

\section{Od teologii do teologiczno-prawnej struktury unitarnej potestas sacra}

\subsection{Historyczne początki i teologiczne założenia}

Swoją teorię władzy kościelnej (potestas sacra) K. Mörsdorf opiera na założeniach teologicznych. To dla twórcy szkoły monachijskiej jest oczywiste, biorąc pod uwagę jego metodologię prawa kanonicznego: kanonistyka jest wszakże „dyscypliną teologiczną o metodzie prawnej” 22 .

Wychodząc zatem od krytyki teorii Rudolfa Sohma (1841-1917), że „istoty Kościoła nie można pogodzić z istotą prawa (kanonicznego)” i że „Kościół nie potrzebuje prawa kanonicznego", tak że obie te rzeczywistości są wobec siebie

20 Co do uczniów K. Mörsdorfa, por. A. Cattaneo, Questioni..., dz. cyt., s. 31-35. Z polskiej kanonistyki trzeba wymienić przede wszystkim R. Sobańskiego, będącego pod wyraźnym wpływem K. Mörsdorfa, jeżeli chodzi o teorię władzy kościelnej, a także J. Krukowskiego; zob. R. Sobański, Kościót jako podmiot prawa, Warszawa 1983, s. 134-173; tenże, Komentarz do kan. 129-144, [w:] J. Krukowski, R. Sobański, Komentarz do Kodeksu Prawa Kanonicznego, t. 1: Księga I. Normy ogólne, red. J. Krukowski, Poznań 2003, s. 212-213; J. Krukowski, Prawo administracyjne w Kościele, Warszawa 2011, s. 48-52.

21 Co do tych zagadnień zob. A. Cattaneo, Questioni..., dz. cyt., s. 77-103, 189-288, 349-356, 407-426.

22 Zob. E. Eichmann, K. Mörsdorf, Lehrbuch des Kirchenrechts auf Grund des Codex Iuris Canonici, t. 1: Einleitung. Allgemeiner Teil und Personenrecht, München-PaderbornWien 1964, s. 36; K. Mörsdorf, Kanonisches Recht als theologische Disziplin, „Seminarium”, R. 15, 1975, s. 802-821. W polskiej kanonistyce tak w szczególności R. Sobański; por. R. Sobański, Metodologia prawa kanonicznego, Warszawa 2009, s. 34-39. 
przeciwstawne, wykluczając się wzajemnie ${ }^{23}$ - Mörsdorf dochodzi do wniosku przeciwnego. Według monachijskiego profesora rzeczywistość prawna w Kościele istnieje od początku, od Jezusa Chrystusa, a nie dopiero od czasów apostolskich, jak twierdzi R. Sohm²4. Kościół wszak został ukonstytuowany na tajemnicy Wcielenia Syna Bożego ${ }^{25}$. Jakakolwiek zaś misja i władza kościelna znajduje swój historyczny i konkretny początek w Jezusie Chrystusie ${ }^{26}$.

To Jezus Chrystus przekazał swoją misję uczniom słowami pełnymi autorytetu, władzy danej Mu przez Ojca ${ }^{27}$ : „Jak Ojciec Mnie posłał, tak i Ja was posyłam” (J 20, 21). Greckie słowo apostolos („posłany”) jest tłumaczeniem dosłownym terminu hebrajsko-aramejskiego šālîah, który z kolei oznacza pełnomocnika bez ograniczeń w sensie techniczno-prawnym ${ }^{28}$, alter ego mocodawcy $^{29}$. Instytucja šālîh h, stosowana w kontekście kultury hebrajskiej w czasach Jezusa, powinna być odczytywana w ten sposób wobec apostołów. Stąd apostołowie reprezentują Pana Jezusa nie tylko w sensie symbolicznym, ale przede wszystkim - prawnym (sic!), i to w ten sposób, że akty prawne dokonane przez apostołów-pełnomocników wiążą ich Pana-mocodawcę ${ }^{30}$.

23 Por. R. Sohm, Kirchenrecht, vol. 1: Die geschichtlichen Grundlagen, Leipzig 1892, s. 23, cyt. za A. Cattaneo, Questioni..., dz. cyt., s. 67, przyp. 54, 55; K. Mörsdorf, Altkanonisches "Sakramentenrecht”. Eine Auseinandersetzung mit den Anschaungen Rudolf Sohms über die inneren Grundlagen des Decretum Gratiani, „Studia Gratiana”, R. 1, 1953, s. 489.

24 Zob. tamże.

${ }_{25}$ Por. K. Mörsdorf, Die Entwicklung der Zweigliedrigkeit der kirchlichen Hierarchie, „Münchener Theologische Zeitschrift”, R. 3, 1952, nr 1, s. 2.

${ }_{26}$ Do tego później - jak już o tym była mowa w punkcie poprzedzającym - odwoła się Sobór Watykański II.

27 Słowa Jezusa Chrystusa są władcze i mają moc wiążącą (nakazującą w sensie prawnym), gdyż przemawia On jako Syn Boży, Słowo Wcielone. Wielokrotnie można to zauważyć w Piśmie Świętym, podobnie zresztą jak prawny (tj. wiążący na sposób nakazu) charakter Jego wypowiedzi; por. Mt 5, 21-22; 7, 29; 9, 1-8; 28, 19; Mk 16, 16; J 3, 18; 5, 31-40; 8, 22-20; 9, 30-34. Tak objawiona władza Boga ma zatem podstawę formalno-prawną. Por. K. Mörsdorf, Altkanonisches „Sakramentenrecht”..., dz. cyt., s. 493-494.

${ }_{28}$ Zob. K. H. Regenstorf, á ment, red. G. Kittel, t. 1, Stuttgart 1933, s. 397-399, 415-420. Inne użycie tego terminu w tym właśnie sensie prawnym por. J 13, 16: „Sługa nie jest większy od swego pana ani wystannik od tego, który go postat' (kursywa - P. S.).

29 Por. K. Mörsdorf, Die Entwicklung..., dz. cyt.; tenże, Kanonisches Recht..., dz. cyt., s. 810 .

30 Zob. tamże. 
Ta misja Pana Jezusa trwa więc w apostołach oraz w ich następcach, a ponadto została związana z przekazaniem władzy kościelnej ${ }^{31}$, nazwanej przez Sobór Watykański II potestas sacra.

Misję apostolską (i związaną z nią władzę kościelna) powierzył Pan Jezus apostołom jedynie - jak twierdzi K. Mörsdorf - poprzez swoje słowo, bez znaków symbolicznych. To apostołowie dołączyli do tego przekazania misji gest nałożenia rąk, znany już w liturgii hebrajskiej ${ }^{32}$. W ten sposób słowo i sakrament (Wort und Sakrament) konstytuują Kościół, będąc elementami różnymi, ale występującymi i działającymi jednocześnie w Kościele, a to ze względu na ich strukturalne powiązanie ${ }^{33}$. To bowiem, co jest właściwe dla słowa, staje się widzialne i namacalne w sakramencie, przyjmując postać symbolu, także prawnego ${ }^{34}$. Podobnie jak Kościół jest „jedną acz złożoną rzeczywistością” („una realitas complexa”), tak też i jedną, jakkolwiek złożoną rzeczywistością jest sakramentalność Kościoła ${ }^{35}$, a nadto - jak się wypowiedzą uczniowie ze szkoły K. Mörsdorfa ${ }^{36}$ - władza kościelna.

\subsection{Ewolucja historyczna i teologiczne niezrozumienie jedności władzy kościelnej w jej różnorodności}

Przy wielu okazjach profesor z Monachium analizuje fenomen jedności struktury władzy kościelnej z punktu widzenia historycznego ${ }^{37}$. Dostrze-

${ }^{3}$ Por. tenże, Zur Grundlegung des Rechtes der Kirche, „Münchener Theologische Zeitschrift", R. 3, 1952, nr 4, s. 338.

32 Zob. tenże, Altkanonisches „Sakramentenrecht”..., dz. cyt., s. 496-497; tenże, Die Entwicklung..., dz. cyt., s. 3.

33 Por. tenże, Altkanonisches „Sakramentenrecht”..., dz. cyt., s. 492; tenże, Kanonisches Recht..., dz. cyt., s. 815. Reminiscencją tej teorii K. Mörsdorfa jest - jak się wydaje - kan. 213 KPK.

34 Zob. tenże, Altkanonisches „Sakramentenrecht”..., dz. cyt., s. 494; tenże, Wort und Sakrament als Bauelemente der Kirchenverfassung, "Archiv für katholisches Kirchenrecht”, R. 134, 1965, nr 1, s. 77-78.

35 Por. tenże, Kanonisches Recht..., dz. cyt., s. 816.

36 Zwłaszcza zob. E. Corecco, Natura e struttura della „sacra potestas” nella dottrina e nel nuovo Codice di Diritto Canonico, [w:] E. Corecco, Ius et communio. Scritti di Diritto Canonico, red. G. Borgonovo, A. Cattaneo, t. 1, Casale Monferrato-Lugano 1997, s. 463-464.

37 Przykładowo por. K. Mörsdorf, Weihegewalt und Hirtengewalt in Abgrenzung und Bezug, „Miscellanea Comillas”, R. 16, 1951, nr 2, s. 107-108; tenże, Die Entwicklung..., 
ga - jak to zostało już wykazane - że ta jedność wywodzi się z przekazu misji Chrystusowej, dokonanej przez samego Pana. W pierwszym tysiącleciu chrześcijaństwa dokonywano święceń zawsze z myślą o konkretnym urzędzie kościelnym (tzw. święcenia relatywne) ${ }^{38}$. Stąd też nie rozróżniano władzy święceń (potestas ordinis) od władzy rządzenia (postestas regiminis, iurisdictionis) ${ }^{39}$. Obie bowiem są jedną władzą świętą (potestas sacra), działającą razem, a nigdy oddzielnie; ściśle, wewnętrznie ze sobą powiązane - tak, że gdy działa jedna, działa również i druga ${ }^{40}$.

Dlatego problemem stały się sakramenty udzielane przez kapłanów, którzy popadli w schizmę czy w herezję. Skoro nie posiadali oni już jurysdykcji, to czy mogli ważnie udzielać sakramentów? Według poglądów montanistów (np. Tertulian, ok. 150 [160]-240), św. Cypriana (ok. 200 [210]-258) czy donatystów (IV-V wiek) sakramenty udzielane przez schizmatyków czy heretyków były nieważne. Dopiero św. Augustyn (354-430) rozwinął naukę o charakterze niezatartym chrztu i święceń, a stąd wyciągnął wniosek o ważności sakramentów udzielanych przez jakiegokolwiek wyświęconego, nawet schizmatyka czy heretyka ${ }^{41}$. Skoro nie potrafiono oddzielić władzy rządzenia od władzy święceń, konsekwentnie zakazywano tzw. święceń absolutnych pod sankcją „nieważności” (akyros, irritus) święceń (kan. 6 soboru chalcedońskiego w $451 \mathrm{roku}^{42}$ ). Chodziło jednak o „tzw. nieważność praktyczną” święceń (eine sogennante praktische Nullität), czyli wyłączenie władzy rządzenia związanej z władzą święceń. Takie święcenia absolutne bowiem są „pozbawione mocy (kraftlos) i nie mogą być nigdzie skuteczne (können nirgends wirken)”³.

dz. cyt., s. 1-16; tenże, Altkanonisches „Sakramentenrecht”..., dz. cyt., s. 496-501; tenże, De conceptu Officii Ecclesiastici, „Apollinaris”, R. 33, 1960, nr 1-4, s. 79-81; tenże, De sacra potestate..., dz. cyt., s. 49-51; tenże, Munus regendi et potestatas iurisdictionis, [w:] Acta conventus internationalis canonistarum Romae diebus 20-25 mai 1968 celebrati, Città del Vaticano 1970, s. 206-210.

38 Por. K. Nasiłowski, $Z$ problematyki okresu święceń relatywnych, „Prawo Kanoniczne”, R. 28, 1985, nr 1-2, s. 97-208.

39 Zob. tenże, Die Entwicklung..., dz. cyt., s. 4-5.

40 Por. A. Cattaneo, Questioni..., dz. cyt., s. 141.

${ }_{41}$ Zob. zwłaszcza K. Mörsdorf, Die Entwicklung..., dz. cyt., s. 4-12.

${ }_{42}$ Tekst tego kanonu w oryginałach grackim i łacińskim oraz w tłum. T. Wnętrzak zob. Dokumenty soborów powszechnych. Tekst grecki, taciński, polski, opr. A. Baron, H. Pietras, t. 1, Kraków 2002, s. 230-231.

43 Por. K. Mörsdorf, Die Entwicklung..., dz. cyt., s. 12. 
Zasada terytorialnego związania święceń biskupich z urzędem kościelnym, która powodowała nieumiejętność rozróżnienia w jednej potestas sacra różnorodności, tj. potesas ordinis i potestas regiminis - zaczęła jednak ustępować wobec praktyki Kościoła. Od III wieku przenosi się biskupów do innych siedzib aniżeli te, dla których zostali wyświęceni. W połowie IV wieku pojawiają się pierwsze święcenia absolutne, tak na Wschodzie (np. św. Grzegorz z Nazjanzu, ok. 330-389 lub 390), jak i na Zachodzie (dla klasztorów, np. w Kościele iroszkockim, czy instytucja coepiscopus w państwie Franków albo biskupów pomocniczych - Weihbischöfe w krajach germańskich). W średniowiecznej Europie należało zapewnić opiekę duszpasterską tam, gdzie biskup był panem feudalnym i nie przyjmował sakry biskupiej ${ }^{44}$.

W ten sposób zrodziła się teoria dwubiegunowa władzy kościelnej, która zaczęła rozróżniać i oddzielać władzę święceń od władzy rządzenia ${ }^{45}$. Zdaniem K. Mörsdorfa początki tego zjawiska sięgają nie czasów samego Gracjana (XII wiek), lecz następującej po nim szkoły dekretystów, która zaczęła komentować jego Decretum ${ }^{46}$. Co więcej, jeszcze w epoce przedreformacyjnej obie te władze - w rzeczywistości jednak będące jedną potestas sacra - zaczęly być separowane od siebie. Natomiast w trydenckim Katechizmie Rzymskim (1566) to zjawisko odseparowania władzy święceń od władzy rządzenia jest zupełnie widoczne. $\mathrm{O}$ ile bowiem władza święceń odnosiła się do realnego Ciała Chrystusa w Najświętszej Eucharystii, o tyle władza rządzenia zwracała się do Kościoła jako Ciała Mistycznego Chrystusa $^{47}$. W ten sposób dano początek błędnemu przeciwstawieniu: sakramenty - prawo $^{48}$. Takie - niewłaściwe, bo separujące - rozumienie

44 Zob. tamże, s. 12-14.

45 Więcej na temat tej teorii, oczywiście, z konieczności w sposób schematyczny zob. P. Skonieczny, Teorie..., dz. cyt., s. 460-461.

${ }^{46}$ Por. tenże, Altkanonisches „Sakramentenrecht”..., dz. cyt., s. 500-501.

47 Zob. tenże, Munus..., dz. cyt., s. 206-207, gdzie cytat z Catechismus Romanus, pars II, cap. 7, q. 6 („Ordinis potestas ad verum Christi Domini Corpus in sacrosancta Eucharistia refertur. Iurisdictionis vero potestas tota in Christi Corpore mystico versatur"); tenże, Weihegewalt..., dz. cyt., s. 103-105; tenże, Einheit in der Zweiheit. Der hierarchische Aufbau der Kirche, „Archiv für katholisches Kirchenrecht”, R. 134, 1965, nr 1, s. 81, cyt. za A. Cattaneo, Questioni..., dz. cyt., s. 142-143, przyp. 22.

${ }^{4}$ Por. K. Mörsdorf, Das Weihesakrament in seiner Tragweite für den verfassungsrechtlichen Aufbau der Kirche, „Ephemerides Theologicae Lovanienses”, R. 52, 1976, z. 1, s. 199. 
władzy kościelnej znalazło swój wyraz także w poprzednio obowiązującym kodeksie z 1917 roku $^{49}$.

Z prawdziwą krytyką K. Mörsdorfa spotkała się jednak nie teoria dwubiegunowa, lecz teoria trzybiegunowa władzy kościelnej50 ${ }^{50}$ której już same korzenie protestanckie (kalwińskie) budziły podejrzenia ${ }^{51}$. Na podstawie doktryny o tria munera Christi, czyli Chrystusa jako Kapłana, Króla i Proroka, zbudowano teorię o trójpodziale władzy kościelnej odpowiednio na: władzę uświęcania, władzę rządzenia i władzę nauczania (tria munera Ecclesiae). Teoria ta nie tylko jest niezgodna z tradycją katolicką (kanoniczna), ale również burzy rozumienie samej potestas sacra jako jednej władzy kościelnej i rodzi problem relacji pomiędzy tak rozumianymi władzami ${ }^{52}$.

\subsection{Teoria unitarna struktury władzy kościelnej K. Mörsdorfa: potestas sacra - jedność w różnorodności}

Analiza teologiczna i historyczna władzy kościelnej prowadzi K. Mörsdorfa do teorii unitarnej (acz niejednorodnej) struktury tejże władzy. Zawsze mowa jest o jednej władzy kościelnej, tj. postestas sacra (die heilige Gewalt), czyli - jak ją definiuje mistrz szkoły monachijskiej - „władzy Kościoła, ustanowionej przez samego Jezusa Chrystusa, która też powinna być wykonywana w Jego imieniu przy realizacji misji powierzonej Kościołowi” ${ }^{53}$.

Widać wyraźnie w tej definicji władzy świętej trzy elementy. Pierwszy element to wskazanie źródła tej władzy - Jezusa Chrystusa. Następny element dotyczy określenia charakteru prawnego potestas sacra. Chodzi

\footnotetext{
49 Zob. kan. 109 KPK z 1917 r., cyt. przez K. Mörsdorfa, Munus..., s. 207.

so Przykładowo: tenże, Weihegewalt..., dz. cyt., s. 95-96; tenże, De conceptu..., dz. cyt., s. 75-76; tenże, De sacra potestate..., dz. cyt., s. 47-49.

sI W kanonistyce przejęto tę teorię poprzez dzieła kanonistów niemieckich - F. A. Walthera (1727-1769) i G. Phillipsa (1804-1872); zob. J. Fuchs, Weihesakramentale Grundlegung kirchlicher Rechtsgewalt, „Scholastik”, R. 16, 1941, z. 4, s. 496-501, cyt. przez K. Mörsdorfa, Weihegewalt..., dz. cyt., s. 96, przyp. 1.

s2 Por. K. Mörsdorf, De sacra potestate..., dz. cyt., s. 48-49. Niektóre z zarzutów co do teorii trzybiegunowej zob. P. Skonieczny, Teorie..., dz. cyt., s. 461-462.

53 K. Mörsdorf, Potestà sacra, [w:] K. Mörsdorf, Fondamenti del diritto canonico, red. i tłum wł. S. Testa Bappenheim, Venezia 2008, s. 261 (niestety, Autorowi nie udało się dotrzeć do tekstu oryginalnego, zatytułowanego Heilige Gewalt, [w:] Sacramentum mundi, t. 2, Freiburg-Basel-Wien 1968, s. 582).
} 
o pełnomocnictwo bez ograniczeń - dla apostołów i ich następców; stąd mowa jest o działaniu „w imieniu” i na rzecz Mocodawcy. Wreszcie, w ostatnim elemencie został określony zakres pełnomocnictwa - misja Kościoła, która - skądinąd wiadomo z innych tekstów monachijskiego profesora opiera się na słowie i na sakramentach.

Tak rozumiana władza kościelna doskonale odpowiada koncepcji potestas sacra Soboru Watykańskiego II, a nawet - jak już to było wyżej sygnalizowane - K. Mörsdorf jako peritus Soboru i doradca niemieckojęzycznych ojców soborowych (biskupa J. Höffnera) wpłynął na kształt tej instytucji w aktach Vaticanum $I T^{5}$.

W istocie rzeczy - jak wielokrotnie podkreśla twórca szkoły monachijskiej $^{55}$ - nie ma sprzeczności między teorią unitarną i teorią dwubiegunową władzy kościelnej. Władza święceń i władza rządzenia są „dwoma kolumnami” z prawa Bożego, które konstytuują Kościół i odzwierciedlają jego nienaruszalną strukturę ${ }^{56}$. Nie można ich przeciwstawiać sobie, jak nie można tworzyć antynomii między sakramentem a prawem ${ }^{57}$. Kiedy działa władza święceń, jednocześnie działa też władza rządzenia (co najlepiej - zdaniem K. Mörsdorfa - widać w sakramencie pojednania czy bierzmowania ${ }^{58}$ ). $\mathrm{Z}$ drugiej zaś strony już w konsekracji biskupiej znajduje się fundament wła-

s4 Zob. A. Cattaneo, Questioni..., dz. cyt., s. 184-185 z przyp. 106; S. Testa Bappenheim, Prologo, [w:] K. Mörsdorf, Fondamenti..., dz. cyt., s. 9. Pośrednio przyznaje to sam K. Mörsdorf, por. tenże, De legis Ecclesiae fundamentalis condendae sensu et fine, [w:] De Lege Ecclesiae Fundamentali condenda. Conventus canonistarum hispano-germanus Salmanticae diebus 20-23 Januarii 1972 habitus, Salmanticae 1974, s. 58.

ss Przykładowo: K. Mörsdorf, De sacra potestate..., dz. cyt., s. 49; tenże, Munus..., dz. cyt., s. 206; tenże, Potestà..., dz. cyt., s. 267.

56 Por. K. Mörsdorf, Weihegewalt..., dz. cyt., s. 95.

57 Zob. tamże, s. 96.

58 Przykładowo por. tamże, s. 100-103. Według niektórych uczniów K. Mörsdorfa argument ten stracił swoją siłę, jako że w kodeksie z 1983 roku nie stanowi się już o iurisdictio w odniesieniu do upoważnienia (facultates) do spowiadania (por. kan. 966-976) czy bierzmowania (por. kan. 882, 883, $884 \$ 1$ i 2, 887); zob. E. Corecco, Natura..., dz. cyt., s. 476-482; A. Cattaneo, Questioni..., dz. cyt., s. 172, 390-399. Autorzy ci postrzegaja działanie facultates w sakramentach jako „konkretyzację czy też bliższe określenie prawne” władzy kościelnej (die Konkretisierung oder nähere rechtliche Umschreibung einer Vollmacht), która jednak przekazywana jest w akcie święceń; por. P. Krämer, Die geistliche Vollmacht..., dz. cyt., s. 152. Z takim stanowiskiem zgodzić się nie można. Upoważnienie do spowiadania czy też do sprawowania innych sakramentów wcale nie różni się od iurisdictio w daw- 
dzy rządzenia (Grundbestand an oberhirtlichen Gewalt ${ }^{59}$ ), zwany też „fundamentem ontologicznym" (fundamentum ontologicum ${ }^{60}$ ). To właśnie dlatego tylko duchowni mogą sprawować władzę rządzenia w Kościele (por. kan. 129 $\$ 1$ KPK z 1983 roku) ${ }^{61}$. O ile władza święceń może być nazwana „zasada dającą życie” (Lebensprinzip, principium generans), o tyle władza rządzenia może być określona „zasadą porządkującą” lub „dyscyplinującą” tę pierwszą (Ordnungsprinzip, principium dirigens) ${ }^{62}$. Władza święceń ze swej natury ma charakter powszechny (eine gemeinkirchliche Gewalt), natomiast władza rządzenia - z wyjątkiem Papieża i Kolegium Biskupów - jest ograniczona

nym stanie prawnym: nadal ma ono przecież charakter prawny i angażuje władzę rządzenia; por. W. Aymans, K. Mörsdorf, Kanonisches Recht..., dz. cyt., s. 403.

59 Por. K. Mörsdorf, Weihegewalt..., dz. cyt., s. 105-106, 108.

6 Zob. tenże, De sacra potestate..., dz. cyt., s. 54.

${ }_{61}$ Por. tenże, Die Stellung der Laien in der Kirche, „Revue de Droit Canonique”, R. 1011, 1960-1961, nr 3-4 [z 1960], nr 1 [z 1961], s. 224. Duchowni są po prostu przez święcenia ontologicznie zdolni do sprawowania władzy świętej tak, że święcenia wyciskają na nich „osobisty niezatracalny charakter” (eine bleibende personale Prägung), aby zastępowali niewidzialną Głowę Kościoła i stawali na czele wspólnoty kościelnej jako jej głowa. W ten sposób święcenia są ukierunkowane konkretnie na urząd pasterski (kościelny), co nie jest tak widoczne przy święceniach absolutnych. Świeckim brakuje tego charakteru wynikającego ze święceń, stąd nie mogą oni być pasterzami. Por. tamże, s. 224-225. Z tych powodów dla K. Mörsdorfa i dla innych uczniów jego szkoły problemem nie do rozwiązania jest sędzia świecki (por. kan. $1421 \$ 2$ KPK z 1983). Natomiast proponowane pozytywne rozwiązania tej aporii nie są przekonywające, a wręcz sztuczne; por. A. Cattaneo, Questioni..., dz. cyt., s. 410-414, wraz z cyt. tamże literaturą w przyp. 8. W każdym razie na gruncie koncepcji unitarnej potestas sacra, tak jak ją rozumie szkoła monachijska - poważne zastrzeżenia teoretyczne budzi dopuszczenie świeckich do urzędu sędziowskiego.

${ }_{62}$ Zob. K. Mörsdorf, Weihegewalt..., dz. cyt., s. 109; tenże, Zur Grundlegung..., dz. cyt., s. 338-339; tenże, De sacra potestate..., dz. cyt., s. 52. Mörsdorf przywołuje tamże obraz krzewu winnego (por. J 15, 1-11), w którym objawiają się dwie siły życiowe Kościoła - siła winorośli, tkwiąca w jej pędach, oraz siła uprawiającego winorośl, który przycina i oczyszcza krzew winny. Obie siły, które działają w Kościele, pochodzą od Boga, ale w różny sposób - dając wzrost, życie (Lebensprinzip: władza świeceń) lub też dyscyplinując poprzez „przycięcia” (Ordnungsprinzip: władza rządzenia). W innym zaś dziele monachijski profesor czerpie z obrazu zawartego w Kol 2, 19, czyli: „[...] Głowy - [Tego], z którego całe Ciało, zaopatrywane i utrzymywane w całości dzięki wiążącym połączeniom członków, rośnie Bożym wzrostem”. W działaniu Głowy objawiają się bowiem dwie siły - dająca życie i dyscyplinująca; to jednak rozróżnienie funkcjonalne (diese funktionelle Unterschiedenheit) nie podważa samej zasady jedności Ciała i Jego Głowy. Por. E. Eichmann, K. Mörsdorf, Lehrbuch..., dz. cyt., s. 244. 
terytorialnie lub personalnie. Jednak to rozróżnienie ma znaczenie jedynie funkcjonalne czy pojęciowe, a w żadnym razie nie dotyczy istoty ${ }^{63}$. Władzy rządzenia w strukturze potestas sacra odpowiadałoby słowo w strukturze Kościoła, natomiast władzy święceń - sakrament ${ }^{64}$.

Obu tych władz nie można zatem oddzielić, tak ściśle są ze sobą wewnętrznie związane, choć można je - pojęciowo jedynie - rozróżnić ${ }^{65}$. Ponadto obie te władze są w swoistych relacjach z tria munera: sanctificandi, docendi i regendi ${ }^{66}$. W rzeczywistości bowiem stanowią one jedną władzę - tę przekazaną przez Jezusa Chrystusa Kościołowi, a którą Sobór Watykański II nazywa potestas sacra.

Schematycznie strukturę władzy kościelnej K. Mörsdorf przedstawił następująco $^{67}$ :

${ }_{63}$ Por. tenże, Weihegewalt..., dz. cyt., s. 109; tenże, De sacra potestate..., dz. cyt., s. 5253; tenże, Munus..., dz. cyt., s. 210-211.

${ }^{64}$ Zob. tenże, Zur Grundlegung..., dz. cyt., s. 338; E. Eichmann, K. Mörsdorf, Lehrbuch..., dz. cyt., s. 16.

6s Por. tenże, Weihegewalt..., dz. cyt., s. 109; tenże, De sacra potestate..., dz. cyt., s. 53. W innej swej pozycji K. Mörsdorf pisze o „powiązaniu” (Verknüpfung) obu władz, które wzajemnie się przenikają (ineinanderfließen); zob. tenże, Abgrenzung und Zusammenspiel von Weihegewalt und Hirtengewalt, „Die Kirche in der Welt”, R. 4, 1951, s. 22, cyt. za A. Cattaneo, Questioni..., dz. cyt., s. 176-177, przyp. 98.

${ }_{66}$ Zob. K. Mörsdorf, De conceptu..., dz. cyt., s. 81-82; tenże, Die Stellung..., s. 225; tenże, De sacra potestate..., dz. cyt., s. 47-49, 53; tenże, Potestà..., dz. cyt., s. 266, 274; tenże, Munus..., dz. cyt., s. 211.

${ }_{67}$ Podobny schemat zob. K. Mörsdorf, De conceptu..., dz. cyt., s. 82. Wyjaśnienie schematu: „Relacja przeciwstawna, w której znajdują się wobec siebie władza święceń i władza rządzenia, może być porównana ze zmieniającymi się ogniskami elipsy. Obie władze są różne co do sposobu ich przekazywania i swojej własnej funkcji. Dążą one jednak bardziej lub mniej do zbliżenia i spotykają się razem w różnych czynnościach sakramentalnych (heilige Handlung), powodując ich skuteczność (Wirkenheit) tak, że razem tworzą ten sam środek okręgu. [...] Tymczasem przeciwstawienie (Polarität) wzajemnych relacji między władzą święceń a władzą rządzenia jest tak duże, że każda z tych dwóch władz ma swoją własną relację do tria munera. W rzeczy samej bowiem tak władza święceń, biorąca swoje źródło w konsekracji, jak i władza rządzenia, pochodząca z misji kanonicznej, uczestniczą - każda na swój sposób - w zakresie (dosł. okręgu) działania (Wirkungskreis) Kościoła, który to zakres działania Kościoła jest opisany przez triadę uświęcania, nauczania i rządzenia. [...] Przez święcenia duchowni stają się zdolni (zeugen), aby uświęcać, nauczać i przewodzić; w ten sposób nieprzekazywalny charakter święceń (Geistesgabe) bierze udział w jakimkolwiek działaniu Kościoła. Misja kanoniczna udziela określonego stanowiska pasterskiego (Hirtenstellung) 


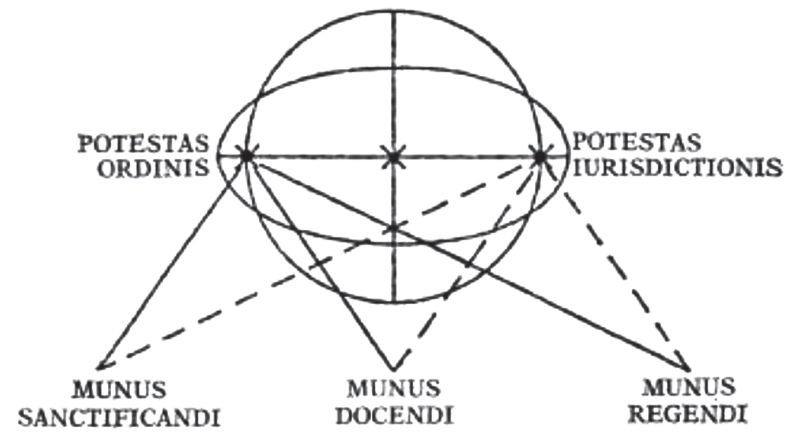

Źródło: A. Cattaneo, Questioni..., dz. cyt., s. 179 z cyt. literaturą.

\section{Teologia communio a natura i sposób przekazywania potestas sacra}

\subsection{Wymiar chrystologiczny i eklezjologiczny potestas sacra}

Tak rozumiana potestas sacra może być wykonywana tylko w communio Kościoła, co więcej, ta wspólnota ma być „hierarchiczna” ${ }^{6}$, jak już była o tym mowa wyżej. W ten sposób potestas sacra nie jest ani władzą ludu Bożego, ani władzą nad ludem Bożym, lecz jest władzą $w$ ludzie Bożym, używając słów jednego z najbliższych uczniów K. Mörsdorfa ${ }^{69}$.

i tym samym konkretnego zadania i pełnej władzy (Vollmacht) do uświęcania, nauczania i przewodzenia. Uświęcanie (Priesteramt), nauczanie (Lehramt) i pasterzowanie (Hirtenamt) nie są urzędami w sensie prawnym (Ämter im rechtlichen Sinne), lecz zadaniami w Kościele i służbą, których wykonanie wymaga (voraussetzt) uczestnictwa we władzy święceń i we władzy rządzenia” (K. Mörsdorf, Kritische Erwägungen zum kanonischen Amtsbegriff, [w:] Festschrift für Karl Gottfried Hugelmann, t. 1, Aalen 1959, s. 390-392, cyt. za: A. Cattaneo, Questioni..., dz. cyt., s. 179-180, przyp. 102; tł. z niemieckiego własne - P. S.).

68 Por. LG 21, 2: „Episcopalis autem consecratio, cum munere sanctificandi, munera quoque confert docendi et regendi, quae tamen natura sua nonnisi in hierarchica communione cum Collegii Capite et membris exerceri possunt" (kursywa - w oryginale).

69 Zob. W. Aymans, Autorità apostolica nel popolo di Dio. Sul fondamento e i limiti del mandato spirituale, [w:] W. Aymans, Diritto canonico e comunione ecclesiale. Saggi di diritto canonico in prospettiva teologica, tł. R. Bertolino, L. Mangels Giannachi, Torino 1993, s. 125 (oryginalny język - włoski, przedruk z: „Communio”, 1977, nr 36, s. 37). 
W rezultacie dochodzi do spotkania dwóch zasad wykonywania potestas sacra, które się uzupełniają - zasady kolegialności (między biskupami, w porządku horyzontalnym: Kollegialitätsprinzip) i zasady personalnej (między Głową Kolegium Biskupów, czyli Papieżem, a poszczególnymi biskupami, w porządku wertykalnym, zwanej przez twórcę szkoły monachijskiej „zasadą jedności Głowy i Ciała”: Strukturprinzip der Haupt-Leib-Einheit) ${ }^{70}$.

Taka wizja chrystologiczna i eklezjologiczna ${ }^{71}$ oraz sama koncepcja jednej acz niejednorodnej potestas sacra - musiały wpłynać na teoretyczne określenie sposobu przekazywania oraz charakteru (natury) władzy kościelnej według naszego autora ${ }^{72}$.

\subsection{Przekazywanie potestas sacra}

Skoro da się odróżnić władzę święceń od władzy rządzenia, jakkolwiek stanowią one „różne strony tego samego medalu”73 - to władza święceń jest

70 Co do - ważniejszej - zasady personalnej por. E. Eichmann, K. Mörsdorf, Lehrbuch..., dz. cyt., s. 563; K. Mörsdorf, Die hierarchische Struktur der Kirchenverfassung, „Seminarium”, R. 18, 1966, nr 2, s. 406-414; tenże, Über die Zuordnung des Kollegialitätsprinzips zu dem Prinzip der Einheit von Haupt und Leib in der hierarchischen Struktur der Kirchenverfassung, [w:] Wahrheit und Verkündigung. Michael Schmaus zum 70. Geburtstag, red. L. Scheffczyk, W. Dettloff, R. Heinzmann, t. 2, München-Paderborn-Wien 1967, s. 1436-1437. Odnośnie do zasady kolegialnej zob. tenże, Die hierarchische Struktur..., dz. cyt., s. 407-409, 412-416; tenże, Über die Zuordnung..., dz. cyt., s. 1437-1439, 14431445.

${ }^{71}$ Także wymiar chrystologiczny należy dostrzec w samej potestas sacra; zob. P. Krämer, Dienst..., dz. cyt., s. 35-37, 102-103.

72 Dostrzegł to już jego uczeń, E. Corecco, różniąc się od swego mistrza zasadniczo co do sposobu postrzegania communio. Według biskupa Lugano communio nie jest elementem potestas sacra, lecz - faktem jako rzeczywistość konstytuująca Kościół. Obecność faktu - bycie we wspólnocie hierarchicznej Kościoła - stwierdza się tak, jak każdy inny fakt; nie podlega on ocenie arbitralnej. Występuje jednak pewien paradoks między communio i potestas sacra. Z jednej bowiem strony communio jest naturalnym środowiskiem, „ontologiczną rzeczywistością kościelną" (la realtà ontologica ecclesiale), w której działa skutecznie potestas sacra, a $\mathrm{z}$ drugiej strony - to potestas sacra uczestniczy w powstawaniu communio hierarchica; por. E. Corecco, Natura..., dz. cyt., s. 469.

73 Dosłownie: zwei Schauseiten der einen Kirchengewalt - K. Mörsdorf, Rechtsprechung und Verwaltung im kanonischen Recht, Freiburg im Br. 1941, s. 2, cyt. za A. Cattaneo, Questioni..., dz. cyt., s. 165, przyp. 76. 
przekazywana drogą sakramentalną w drodze święceń, natomiast władza rządzenia - poprzez missio canonica. O ile władza święceń jest nieodłącznie (wewnętrznie, ontologicznie) związana z osobą wyświęconego i nie może być na przykład delegowana ani zniesiona, o tyle władza rządzenia dotyczy urzędu kościelnego i stąd może być delegowana i odwołana ${ }^{74}$.

Od razu jednak trzeba zastrzec, że władza rządzenia w przypadku biskupa ma swój fundament w samej sakrze biskupiej (Grundbestand an oberhirtlichen Gewalt), o czym już była mowa. Konsekwentnie należy powiedzieć, że biskup konsekrowany otrzymuje bezpośrednio od Pana Boga potestas sacra nie tylko w znaczeniu władzy święceń, ale również w sensie owej fundamentalnej podstawy władzy rządzenia (Grundbestand an oberhirtlichen Gewalt). Papież natomiast w drodze misji kanonicznej przekazuje biskupowi bezpośrednio pełnię władzy rządzenia w odniesieniu do konkretnego Kościoła partykularnego $^{75}$.

Nie można ponadto oddzielić działania jednej władzy od drugiej, tak jak nie da się odseparować działania słowa i działania sakramentu w Kościele. Missio canonica zatem ukierunkowuje (kontroluje) władzę święceń jako Ordnungsprinzip ${ }^{76}$. To właśnie dzięki misji kanonicznej rodzą się relacje: przełożony - podwładny, pasterz - wierny, communio między samymi pasterzami ${ }^{77}$. Jednakże ta misja kanoniczna nie może być udzielona bez koniecznej communio hierarchica biskupa z Papieżem i Kolegium Biskupów ${ }^{78}$.

74 Por. K. Mörsdorf, Weihegewalt..., dz. cyt., s. 99, 109; tenże, Die Entwicklung..., dz. cyt., s. 16.

75 Zob. tenże, Weihegewalt..., dz. cyt., s. 106. Dawną dyskusję, czy biskup otrzymuje władzę rządzenia od samego Pana Boga czy też od Papieża (założenie „albo - albo”: Entweder-Oder), monachijski profesor rozwiązuje na nowy sposób: i od Pana Boga (poprzez przekazanie fundamentu ontologicznego władzy rządzenia w sakrze biskupiej), jak też i od Papieża (poprzez misję kanoniczną do konkretnego Kościoła partykularnego; założenie „i - i”: Sowohl-Als auch); por tamże.

76 Por. tamże, s. 101.

77 Zob. tenże, Potestà..., dz. cyt., s. 272-273.

78 Por. LG 24, 2: „Episcoporum autem missio canonica fieri potest per legitimas consuetudines, a suprema et universali potestate Ecclesiae non revocatas, vel per leges ab eadem auctoritate latas aut agnitas, vel directe per ipsum Successorem Petri; quo renuente seu communionem Apostolicam denegante, Episcopi in offcium assumi nequeunt”; w tł. polskim: „Misja kanoniczna biskupów może być udzielana na mocy prawowitych zwyczajów, o ile ich nie odwołała najwyższa i powszechna władza Kościoła, albo na mocy praw przez tę władzę 
Żaden kapłan (biskup czy prezbiter) nie może zostać pasterzem, czyli głową powierzonej sobie części ludu Bożego, bez misji kanonicznej. To ona bowiem aktualizuje władzę rządzenia, która odpowiada zasadzie kolegialności, podczas gdy święceniom podporządkowana jest zasada jedności Głowy i Ciała (zasada personalna) ${ }^{79}$. W ten sposób misja kanoniczna nie jest li tylko elementem formalnym, zewnętrznym wobec samej potestas sacra, lecz staje się elementem materialnym, istotnym, który ją wspóttworzy, podobnie jak konstytuuje communio hierarchica ${ }^{80}$.

ogłoszonych lub uznanych, bądź też bezpośrednio przez następcę Piotra; jeśli natomiast on wzbrania się lub odmawia przyjęcia do wspólnoty (communio) apostolskiej, biskupi nie moga być powotywani na urząd" (kursywa - P. S.).

${ }_{79}$ Zob. K. Mörsdorf, Das neue Volk Gottes und die Teilhabe der Laien an der Sendung der Kirche, [w:] Ecclesia et Ius. Festgabe für Audomar Scheuermann zum 60. Geburtstag, red. K. Siepen, J. Weitzel, P. Wirth, München-Paderborn-Wien 1968, s. 103-104, cyt. za A. Cattaneo, Questioni..., dz. cyt., s. 193-194, przyp. 119. Jeden z uczniów profesora $\mathrm{z}$ Monachium zauważa, że w święceniach prezbiteratu i biskupstwa są obecne dwa wymiary - eklezjologiczny (odpowiedzialność pasterza wobec Kościoła) i chrystologiczny (odpowiedzialność za [za]dany dar Chrystusa). Pasterze reprezentują nie tylko Kościół, ale i Głowę Kościoła, czyli Chrystusa; por. P. Krämer, Dienst..., dz. cyt., s. 115.

8o Por. rozważania nie wprost w odniesieniu do Gracjana: K. Mörsdorf, Altkanonisches „Sakramentenrecht”..., dz. cyt., s. 500. Inaczej natomiast w wersjach jednorodnych teorii unitarnej władzy kościelnej, gdzie missio canonica staje się elementem tylko formalnym, zewnętrznym wobec samej istoty potestas sacra. I tak według W. Bertramsa potestas sacra, przekazana niejako wewnętrznie w drodze święceń, potrzebuje być uzewnętrzniona strukturalno-prawnie poprzez włączenie do hierarchica communio, a tę rolę spełnia missio canonica; por. W. Bertrams, De constitutione Ecclesiae simul charismatica et institutionali, [w:] W. Bertrams, Quaestiones fundamentales iuris canonici, Roma 1969, s. 279. Również wg E. Corecco potestas sacra ma jedną, a nadto jednolitą oraz niepodzielną strukturę o charakterze sakramentalnym i stąd jest przekazywana jedynie poprzez święcenia, a wykonywana w communio plena z Biskupem Rzymu i Kolegium Biskupów, o czym zaświadcza missio canonica, bo sama communio nie należy przecież do potestas sacra. Misja kanoniczna determinuje jedynie wykonywanie władzy kościelnej, ale jej nie przekazuje; por. E. Corecco, Natura..., dz. cyt., s. 466-469, 476, 481; A. Cattaneo, Questioni..., dz. cyt., s. 406. W podobnym duchu wypowiada się też P. Krämer, według którego całość potestas sacra jest przekazywana w drodze sakramentalnej, a jej wykonywanie nie może zależeć od czysto pozytywistycznego kryterium, jakim jest misja kanoniczna jako element zewnętrzny. Wykonywanie potestas sacra zależy od możliwości urzeczywistnienia słowa i sakramentu w kościelnej communio, czyli to ekonomia zbawienia ustanawia granice dla wykonywania - i tylko wykonywania, a nie dla przekazywania - potestas sacra; P. Krämer, Dienst..., dz. cyt., s. 100-111; tenże, Die geistliche Vollmacht..., dz. cyt., s. 153-154. 
Można zatem stwierdzić, że według K. Mörsdorfa przekazywanie potestas sacra odbywa się nie tylko na drodze święceń, ale również poprzez misję kanoniczną ${ }^{81}$.

\subsection{Natura sakralna potestas sacra}

Jakkolwiek sam profesor z Monachium nie zajmował się wprost zagadnieniem charakteru (czy też natury) potestas sacra, to jednak z wyżej przedstawionych jego poglądów można wyciągnąć wnioski odnośnie do tego zagadnienia.

Według Mörsdorfowej teorii potestas sacra nie ma charakteru tylko sakramentalnego ani tylko jurysdykcyjnego (prawnego czy formalnego); jej struktura jest niejednorodna. Zatem nie można stwierdzić, że potestas sacra ma charakter sakramentalny albo niesakramentalny (jak to czynią teorie unitarne władzy kościelnej w wersjach jednorodnych ${ }^{82}$ ).

Nie można też dojść do wniosku, że potestas sacra ma charakter sakramentalno-jurysdykcyjny (jak w teorii dwubiegunowej czy trzybiegunowej ${ }^{83}$ ). Jak bowiem wyżej przedstawiono, obie „natury” potestas sacra - władzy święceń (sakramentalna) i władzy rządzenia (jurysdykcyjna) - wzajemnie się przenikają, są wewnętrznie i nierozddzielnie związane, a dają się odróżnić tylko pojęciowo.

Biorąc pod uwagę te właśnie cechy potestas sacra - jej jedność w różnorodności, przy czym ta jedność jest nie tylko formalna, ale i ontologiczna - taką naturę władzy kościelnej można określić jako p a t e r s k ą ${ }^{84}$ lub - lepiej ${ }^{85}$ s a k r a l n ą. Nazywając zatem władzę kościelną - s a k r a l n ą, czyli posługując się sformułowaniem soborowym, wskazuje się w ten sposób nie tylko na jej wyjątkową naturę, ale i na pochodzenie tej władzy (Jezus Chrystus) i cel (uświęcenie, zbawienie człowieka - por. kan. $1752 \mathrm{KPK}$ ).

\footnotetext{
8I Ten sposób przekazywania władzy kościelnej został w innym miejscu nazwany teorią mieszaną; por. P. Skonieczny, Teorie..., dz. cyt., s. 465.

82 Bliżej na ten temat zob. tamże, pkt I.3, ad 1 i 2.

${ }_{3}$ Por. tamże, pkt I.3, ad 3.

${ }_{8}$ Tak właśnie, zob. tamże.

${ }^{85}$ W celu uniknięcia dwuznaczności z terminologią niemiecką, w której to pojęciu Hirtengewalt („władza pasterska”) odpowiada polskie określenie „władza rządzenia”.
} 


\section{Zakończenie: praktyczne konsekwencje teorii}

Klaus Mörsdorf wypracował teorię władzy kościelnej, która najbardziej chyba odpowiada koncepcji soborowej potestas sacra ${ }^{86}$. Kodeks prawa kanonicznego z 1983 roku nie przejął tej koncepcji do końca, unikając wyrażenia potestas sacra, jakkolwiek podzielając szereg jej szczegółowych rozwiązań, zwłaszcza w sformułowaniu kan. $129 \$ 1 \mathrm{KPK}^{87}$.

Nie da się też - jak się wydaje - pogodzić niektórych rozwiązań kodeksowych odnośnie do wykonywania potestas sacra przez świeckich ${ }^{88}$. Jak bowiem wykazał monachijski profesor, a z czym należy się zgodzić, władza kościelna - również w jej wymiarze władzy rządzenia, nie tylko władzy święceń jest w „ontologicznym fundamencie” (Grundbestand) przekazywana poprzez sakrament święceń.

Trzeba ponadto wskazać, rozwijając w tym zakresie myśl K. Mörsdorfa i podążając za jego uczniami, że przekazanie owego Grundbestand władzy rządzenia dokonuje się nie tylko poprzez sakrę biskupią, ale też przez święcenia w stopniu prezbiteratu ${ }^{89}$ (por. kan. 150 i 274 KPK). Oczywiście, biskup otrzymuje pełnię władzy kościelnej, czym różni się od prezbitera. Ale czy

${ }^{86}$ Zresztą, nasz Autor współtworzył tę koncepcję w czasie Soboru Watykańskiego II, jak to już wykazano; zob. wyżej, II.3 z przyp. 51. Jak bliska jest teoria władzy kościelnej K. Mörsdorfa wizji soborowej, nich świadczy i to, że można dojść do podobnych rezultatów, opierając się jedynie na tekstach źródłowych Soboru Watykańskiego II i nie studiując tekstów twórcy szkoły monachijskiej; por. J. Krzywda, Funkcja i znaczenie misji kanonicznej w strukturze władzy kościelnej w świetle Vaticanum II. Studium teologiczno-prawne, Kraków 1996; P. Skonieczny, Teorie..., dz. cyt., s. 466-469.

${ }_{87}$ Przepis ten brzmi: „Potestatis regiminis, quae quidem ex divina institutione est in Ecclesia et etiam potestas iurisdictionis vocatur, ad normam praescriptorum iuris, habilis sunt qui ordine sacro sunt insigniti”; w tł. polskim: „Ci, którzy otrzymali święcenia, zdolni są do sprawowania - zgodnie z przepisami prawa - władzy rządzenia, która jest w Kościele z Bożego ustanowienia i nazywana jest również władzą jurysdykcji”. Podobnie stanowi kan. $979 \$ 1$ Kodeksu Kanonów Kościołów Wschodnich [dalej: KKKW].

${ }_{88}$ Chodzi o urząd sędziego kościelnego; por. kan. $1421 \$ 2$ KPK i kan. $1087 \$ 2$ KKKW.

${ }^{89}$ Por. P. Krämer, Dienst..., dz. cyt., s. 116, gdzie - jak podreśla - prezbiterzy mają tę władzę kościelną „tylko w jedności z Biskupem i w zależności od niego” (nur in Gemeinschaft mit dem Bischof und in Abhängigkeit von diesem). Zresztą, sam twórca szkoły monachijskiej sugeruje taką myśl; por. K. Mörsdorf, Potestà..., dz. cyt., s. 274, pkt IV in princ. 
i prezbiterzy nie mogą wykonywać tej władzy w zakresie ${ }^{90}$ wykonawczym (jako wikariusze generalni czy biskupi albo administratorzy diecezji - por. kan. $425 \$ 1$ w zw. z kan. 426, kan. $478 \$ 1$ i 479 KPK) lub sądowniczym (por. kan. 1420 i kan. $1421 \$ 1 \mathrm{KPK}$ )? Czy i prezbiterzy nie powinni stanowić communio z Biskupem swojej diecezji oraz między sobą jako prezbiterium (por. kan. $369 \mathrm{KPK}$ )?

Nie wydaje się w końcu, aby słuszne było podążanie za tymi uczniami szkoły monachijskiej, którzy - opierając się na myśli swego Mistrza - redukują naturę potestas sacra do potestas ordinis ${ }^{11}$, widząc w misji kanonicznej jedynie element formalny, zewnętrzny, obcy do samej istoty władzy kościelnej, która ma być - według nich - tylko sakramentalna ${ }^{92}$. Gdyby tak miało być, to potestas sacra nie można by było delegować ${ }^{\prime 3}$. Co więcej, wyrzucenie władzy rządzenia poza strukturę wewnętrzną jednej postestas sacra, doprowadza do stworzenia nowej, zewnętrznej struktury. To z kolei oznacza powrót do teorii dwubiegunowej władzy kościelnej (sic! $)^{94}$. W końcu władza rządzenia jest $\mathrm{z}$ ustanowienia Bożego, a nie tylko kościelnego (kan. 129 \$ $1 \mathrm{KPK}$, kan. 979 \$ 1 KKKW: „ex divina institutione est in Ecclesia”) ${ }^{95}$, a zatem nadawanie jej roli tylko formalnej jest niezgodne z Bożym postanowieniem.

Podobnie zob. J. Wroceński, Rola i zadania prezbiterium w życiu Kościoła partykularnego. (Studium historyczno-prawne), Warszawa 1998, s. 232-235.

90 W tym miejscu trzeba zwrócić uwagę na błędne - jak się wydaje - sformułowanie w kodeksach łacińskim i wschodnim, które stanowią o "potestas legislativa”, "potestas exsecutiva” i "potestas iudicialis” (zwłaszcza w kan. 135 KPK i 985 KKKW, ale i w wielu innych miejscach). Tymczasem jest tylko jedna władza kościelna, jakkolwiek w różnych funkcjach (zakresach). To uproszczenie - z zupełnie nieadekwatnym do konstytucji Kościoła modelem Monteskiuszowskim - powielane jest powszechnie w literaturze kanonistycznej. Por. P. Skonieczny, Kościelny akt administracyjny wedtug Kodeksu Prawa Kanonicznego z 1983 r. Wprowadzenie dla prawników świeckich, „Casus”, 2012, nr 4 (66), s. 18, http:// www.kolegium.krakow.pl/_files/Casus_nr_66.pdf (18.03.2013).

9I Tak wprost W. Aymans, K. Mörsdorf, Kanonisches Recht..., dz. cyt., s. 391, przyp. 14.

92 Tak właśnie np. E. Corecco, P. Krämer i A. Cattaneo, a nieco inaczej W. Bertrams, o czym była mowa wyżej. Sama koncepcja jednej i jednolitej władzy kościelnej jest jednak bardzo sugestywna.

93 Jako że delegacja nie jest możliwa przy sakramentach, co zresztą zauważa sam E. Corecco, Natura..., dz. cyt., s. 476.

94 Zob. K. Mörsdorf, Potestà..., dz. cyt., s. 278-279.

${ }_{95}$ Podkreśla to W. Aymans, K. Mörsdorf, Kanonisches Recht..., dz. cyt., s. 399. 
Odrzucenie władzy rządzenia jako jednego z wymiarów władzy kościelnej wynika z zanegowania charakteru prawnego misji udzielonej apostołom przez Jezusa Chrystusa, o czym była już mowa wyżej. Tymczasem władza ta rozciąga się również na sakramenty (np. władza „kluczy”" ${ }^{\prime 6}$ ). Stąd oprócz wymiaru sakramentalnego (władzy święceń) władza kościelna ma wymiar prawny (władzę rządzenia).

Trzeba w końcu zauważyć, że struktura potestas sacra odzwierciedla tajemnicę samego Kościoła. Kościół bowiem jest Ciałem Mistycznym Chrystusa, a Chrystus - Głową Kościoła ${ }^{97}$. „Chrystus i Kościół tworzą więc «całego Chrystusa» (Christus totus). Kościół stanowi jedno z Chrystusem"98. Władza kościelna zatem oznacza działanie samego Jezusa Chrystusa jako Głowy (święcenia), ale również Kościoła jako Jego Mistycznego Ciała (aktualizacja poprzez misję kanoniczna). Nie jest tak, że działanie Kościoła jest czymś „zewnętrznym” wobec Jego Głowy, gdyż Chrystus i Kościół tworzą „całego Chrystusa”. Wobec tej tajemnicy Kościoła należy stanąć z wiarą i ją po prostu przyjąć. Dlatego wszystkie próby negujące charakter prawny (wiążący) w sakramentach czy też tworzące z tzw. jurysdykcji (misji kanonicznej) w potestas sacra element „zewnętrzny”, „dodany” lub „tylko formalny” - są niezgodne z prawdą o Kościele. Potestas sacra odbija bowiem samą tajemnicę Kościoła. W rezultacie tylko przyjęcie z wiarą tej tajemnicy Kościoła pozwala na przybliżenie się do tajemnicy potestas sacra.

${ }_{96}$ Zob. Katechizm Kościoła Katolickiego, Poznań 1994, nr 981-983 [dalej: KKK].

97 Por. Kol 1, 18; KKK 792.

98 KKK 795. 


\section{The Potestas Sacra according to Klaus Mörsdorf: Theological Principles, Structure, Mode of Transmission and Nature}

Summary

This article is a short presentation of the theory of the ecclesial power (called Kirchengewalt in German) as found in the Second Vatican Council according to Klaus Mörsdorf, i.e. its theological principles, structure, mode of transmission and nature. The description of the potestas sacra is an opportunity for the Author to reread the concept of the „sacred power" in the Second Vatican Council. The Author himself agrees with Mörsdorf's views, even if not all the positions of the Munich Professor were applied in the present canon law.

Keywords: Klaus Mörsdorf, potestas sacra, sacred power, the Second Vatican Council, canon law 